\title{
Hierarchy and collaborative networks: a study on the colour of culture
}

\author{
Hierarquia e redes colaborativas: um estudo sobre a cor da cultura
}

\author{
Rosileia das Mercês Milagres ${ }^{1}$ (1), Samuel Araujo Gomes da Silva ${ }^{2}$ (), Otavio Rezende ${ }^{3}$ (1) \\ ${ }^{1}$ Fundação Dom Cabral, Belo Horizonte, MG, Brasil. E-mail: rosileiam@fdc.org.br \\ ${ }^{2}$ Universidade Federal de Minas Gerais - UFMG, Centro de Desenvolvimento e Planejamento Regional - \\ CEDEPLAR, Faculdade de Ciências Econômicas - FACE, Belo Horizonte, MG, Brasil. E-mail: \\ samaraujogo@gmail.com \\ ${ }^{3}$ Universidade Federal da Integração Latino-Americana - UNILA, Foz do Iguaçu, PR, Brasil. E-mail: \\ otrezende@gmail.com
}

How to cite: Milagres, R. M., Silva, S. A. G., \& Rezende, O. (2021). Hierarchy and collaborative networks: a study on the colour of culture. Gestão \& Produção, 28(2), e5041.

http://dx.doi.org/10.1590/1806-9649-2020v28e5041

\begin{abstract}
Some theorists argue that collaborative networks are self-regulated structures, and their coordination strategy must be essentially horizontal and shaded by a "hierarchy." In contrast, others assume that structuring of coordination processes and the establishment of roles is considered to be necessary to achieve the desired results that hierarchise relationships between different actors. Based on this apparent counterpoint, this article is dedicated to understanding the coordination structure of The Colour of Culture (A Cor da Cultura - ACDC) network. Specifically, we are guided by these questions: Can ACDC be characterised as a self-regulated network or as a hierarchical arrangement? What are the functions/dysfunctions of the network's coordination elements on the ACDC network? The operationalisation of the research relied on the use of primary and secondary data: coded, categorised, and classified using the thematic content analysis technique. The results of the case study indicate how the coordination instruments adopted led some to view the ACDC network as a hierarchical arrangement. However, there are indications that it was the adoption of these instruments that facilitated the achievement of these results. That is, the case demonstrates the possibility of coexistence between a network and hierarchical coordination mechanisms.
\end{abstract}

Keywords: Networks; Coordination; Hierarchy; Power; Status.

Resumo: Alguns teóricos defendem que as redes colaborativas são estruturas autorreguladas e que sua estratégia de coordenação deve ser essencialmente horizontal e à sombra de uma "hierarquia". Por outro lado, outros assumem que a estruturação de processos de coordenação e o estabelecimento de papéis, entendidos como necessários para o alcance dos resultados pretendidos, é o que hierarquiza os relacionamentos entre diferentes atores. Com base nesse aparente contraponto, o presente artigo se dedica ao entendimento da estrutura de coordenação da rede A cor da cultura - ACDC. Especificamente, busca-se compreender como os instrumentos de coordenação da rede ACDC se comportaram e como eram percebidos. Para tanto, parte-se das seguintes perguntas: a ACDC pode ser caracterizada como uma rede autorregulada ou

Received Aug. 3, 2018 - Accepted Mar. 17, 2019

Financial support: None.

This is an Open Access article distributed under the terms of the Creative Commons Attribution License, which permits unrestricted use, distribution, and reproduction in any medium, provided the original work is properly cited. 
como um arranjo hierarquizado? E quais são as funções/disfunções dos elementos de coordenação da rede? A operacionalização da pesquisa usou dados primários e secundários, que foram codificados, categorizados e classificados pela técnica de análise de conteúdo. Os resultados apontam que a forma como os instrumentos de coordenação foram adotados levou alguns componentes a perceberem a rede ACDC como um arranjo hierarquizado. Contudo, há indícios que foi a adoção destes instrumentos que permitiu o alcance dos resultados pretendidos. Ou seja, o caso demonstrou a possiblidade de convivência entre uma rede e mecanismos hierárquicos de coordenação.

Palavras-chave: Redes; Coordenação; Hierarquia; Poder; Status.

\section{Introduction}

Collaborative arrangements have become a reality in the business world, given that they are viewed as a response to many challenges that organizations face. Widely studied in the environment of private organisations, this subject has also become relevant with government agencies. In this environment, values such as efficiency and effectiveness continue to guide relationships, but they are increasingly perceived through different lenses that take into account aspects such as democratic values, citizenship, participation, and respect for the specificities and singularities of the different communities that compose modern society (Denhardt \& Denhardt, 2015). As a result, there are increasingly more arrangements involving companies, a variety of organisations such as those linked to civil society, universities, and a number of government entities. It is in this context that we have witnessed the debate on collaborative governance, also known as network governance, i.e., how relationships are coordinated between governments, citizens, civil society entities, companies, and other for- or non-profit organisations (Klijn \& Skelcher, 2007).

Past literature has focused on the phenomenon, seeking to understand it as a whole (Rhodes, 1997; Provan \& Kenis, 2008) and to understand the aspects related to networks, such as 1) leadership (McGuire, 2006); 2) performance (Koppenjan, 2008; Whelan, 2011); 3) trust (Malhotra \& Lumineau, 2011); 4) network structure (Provan \& Kenis, 2005); and 5) type of management and coordination (Provan \& Kenis, 2005; Agranoff, 2006; Schreiner et al., 2009; Emerson et al., 2012). The latter advocates that the governance structure mediates the achievement of results, particularly the coordination mechanisms (Cristofoli et al., 2014; Cristofoli \& Markovic, 2016; Provan \& Kenis, 2005; Provan \& Kenis, 2008).

As there is no apparent unanimity among theorists, the differences in concepts of collaborative networks lie in the elements that compose and influence the results of these arrangements. For Sørensen \& Torfing (2007), for example, these types of coordination/management differ from traditional forms of bureaucratic and hierarchical regulation because they privilege negotiation processes through conflict mediation and "create the rules of the game" without the network losing its self-regulating ability. That is, their institutional design should promote interaction and cooperation among actors who are aware that they are not subject to a "hierarchy" (Sørensen \& Torfing, 2007, p. 173).

In contrast, others like Grandori (2001) believe a priori assertion that firms are hierarchical and networks are not is mistaken. One can also find firms that are not hierarchical, as well as hierarchical collaborative arrangements. For Grandori (2001), Williamson (1991) already made this distinction by differentiating the firm from a centralised organisational arrangement-the hierarchy. 
Some researchers claim that the managerial orientation of networks can be hierarchically focused, or driven by rules (Heranz, 2010) and that although networks are not a bureaucratic structure, they require a division of roles and the establishment of commitments (Agranoff, 2006). Further, Magee \& Galinsky (2008) state that the creation of a formal system of roles and functions or a set of rules for the process of interaction, even if informal, is what structures a hierarchy as a broad phenomenon of social interaction.

Based on this debate, this article seeks to understand the coordination structure of The Colour of Culture (A Cor da Cultura - ACDC) network. Specifically, it focuses on how the ACDC network's coordination instruments have behaved and how they have been perceived. In this way, the following questions guide this analytical exercise: Can ACDC be characterised as a self-regulated network or as a hierarchical arrangement? Additionally, what are the functions/dysfunctions of the network's coordination elements on the ACDC network?

To that end, the remainder of this article is organised as follows: First, we discuss how networks are designed; then, we present the elements that characterise a hierarchical arrangement; followed by the exercise of identifying a possible similarity between networks and hierarchical arrangements. Subsequently, we describe the methodological approach chosen, in addition to the case study and its analysis. Lastly, we conclude with final remarks.

In general terms, the proposed discussion contributes to the debate on the structure of networks through a case study. The results point to a network form of organisation that is different from the one proposed by researchers who advocate that collaborative governance is essentially under the "shadow of hierarchy." It also demonstrates a possible coexistence between a network and hierarchical coordination mechanisms. Finally, we conclude that collaborative governance generates a dysfunctional perception when regarded as a hierarchical arrangement, especially during establishment of formal and informal mechanisms of coordination, while simultaneously facilitating results achievement. This perception met its members' expectations who understood that networks are non-hierarchical structures. For them, it compromised the learning, circulation, and exchange of knowledge.

\section{Hierarchical structures or horizontal structures: what does the literature say?}

For Phillips et al. (2000) and Hardy et al. (2003), networks are cooperative relationships among organisations that do not rely on hierarchical control mechanisms. A network is a relationship negotiated in a continuous communication process. In this line, Sørensen \& Torfing (2007) do not view a network as an organisation because it has no unified goals, the leadership is not capable of imposing formal sanctions, and there is no command by decree. A network also cannot be viewed as an institution because it does not have a well-integrated social interaction system based on relatively fixed rules, norms, and procedures. It is a relatively institutionalised self-regulated system of interactions negotiated between different actors who debate among themselves. They create opportunities for joint decisions, forge policy commitments, and coordinate concrete actions. Conflicts arising from cultural, social, and political differences between autonomous actors prevent networks from becoming stable political institutions.

Rhodes (1997, p. 53) states that networks are self-regulated and combine four key elements: 1) interdependence between organisations; 2 ) inconsistent boundaries among 
the public, private, and voluntary sectors, with continuous interactions among members; 3 ) trust-based interactions governed by negotiated and agreed upon rules; and 4) a significant degree of autonomy vis-à-vis the government, in a context in which the government may indirectly and imperfectly guide the direction of the arrangement. This concept emphasises the interdependence among actors in terms of resources and capabilities but maintains their autonomy, given that they are not subject to the same characteristic structures of hierarchies. Although these are horizontal relationships, this does not imply that the actors are equal in terms of authority and/or allocation of resources. However, given their interdependence, they are aware they will only achieve results through partnership. Consequently, no actor has sufficient power to gain control over others (Sørensen \& Torfing, 2005). Although the government may impose decisions on the partners, the latter have resources as a counterweight, including information, specific knowledge, capital, and political support. By making these resources available, the partners hope to gain political influence by assuming that the government will not adopt policies that are contrary to the interests of the private actors involved (Borzel \& Panke, 2007).

In turn, for Agranoff \& McGuire, (2001), although collaborative networks are not a bureaucratic structure, they require a division of roles and the establishment of commitments. In this sense, Provan and Kenis (2008) note that collaborative governance concerns the use of institutions and structures of authority that allow the allocation of resources, coordination, and control of shared activities. Gulati et al. (2012), in turn, emphasise that absence of formalised authority in the network environment is a fundamental factor for the formation of arrangements that promote and foster interaction among the actors. However, they note that the design of collaborative networks is influenced by 1) the status and formal authority existing in the previous relationship among the actors; 2) bargaining power over asymmetric dependence; 3) forms of compensation through non-pecuniary incentives; and 4) installed communication. For those authors, these network arrangements arise when an organisation attempts to exert control over external partners, despite the lack of authority in a context in which there is no employment relationship. In this manner, network members seek to establish some type of relationship that substitutes formal authority. The standard established for doing so relates to the network's degree of openness (i.e. who selects the members, establishes criteria, and identifies partners as well as the duration and degree of exclusivity of the partnership) or stratification (i.e. the degree of exclusivity of participation in different networks). These factors will define the form of management or governance. In this sense, the network coordination model is dependent on the context in which it was formed. According to Provan \& Kenis (2008), this coordination can take different forms, ranging from structures that privilege collective decision-making to structures that delegate this task to an external organisation.

Therefore, the literature does not seem conclusive. For some, networks are arrangements that favour more horizontal coordination structures, marked by decisions that seek consensus through dissemination of authority among its participants and do not rely on hierarchical controls (Phillips et al., 2000; Hardy et al., 2003; Sørensen \& Torfing, 2007; Sørensen, \& Torfing, 2005). In contrast, researchers such as Gulati et al. (2012) and Provan \& Kenis (2008) argue that the coordination structure may assume a controlling role and exercise authority depending on the conditions, such as those cited above. Faced with this apparent counterpoint, the following question arises: 


\subsection{What characterises a hierarchy?}

The function of the hierarchy is the establishment of order. This, in turn, is a response to uncertainty and chaos. It provides clear directions and subordination that maximises the coordination of different types of activities. Contrary to popular belief, hierarchy as a social phenomenon is not always established by consensus alone. It can be formed based on subjective understandings and can be understood consciously by the individuals/groups involved or not. However, at least one individual/group must be subordinate to at least one other individual/group (Magee \& Galinsky, 2008, p. 353).

This hierarchy can be structured through the creation of a formal system of ordered roles and functions or an informal interaction process. Typically, formal hierarchies result from the increase in complex relationships. Informal hierarchies are based on the judgment of competence and power. They take into account the difference of participation in the execution of a task and the degree of resource interdependence. In general, the hierarchy consists of two factors: 1) social status-respect and admiration exercised by other individuals/groups; and 2) power-asymmetric control of essential/valuable resources. Power guarantees to the actors the possibility to "set agendas, norms for discussion, rules for behaviour, and standards for thought." It is also viewed as something inherent in social relationships and consists of the dependence of others on oneself. "The power of $A$ over $B$ is directly proportional to the dependence of B on A" (Magee \& Galinsky, 2008, p. 353). This interdependence may originate from institutional resources, materials, or socially structured processes (SazCarranza et al., 2015). Status, in turn, is the "respect and admiration given by others to a target individual/group [...] suggests that the basis of respect in organisations is competence, or more precisely, judgements about a target individual's competence." Although causally related and mutually reinforced, these aspects are distinct. Power is based on the resources belonging to the actor, whereas status is conferred to the actor through another actor's evaluation (Magee \& Galinsky, 2008).

Even when reduced, hierarchy is never completely absent, inevitably emerging within and between groups (Magee \& Galinsky, 2008). Therefore, some elements that compose a hierarchical structure show aspects such as the establishment of an order, either through consensually agreed-upon rules or by subjective understandings. This provides coordination and leads individuals to a certain classificatory ordering. The hierarchy may be expressed through a formal system of roles and functions or mechanisms of informal interaction.

\subsection{How do these elements behave in a network?}

Emerson et al. (2012) attest that the network's governance foresees the existence of rules, formal protocols, and protocols developed during the collaboration process. They add instruments such as routines, contracts, councils, and committees. It is the responsibility of regular governance to make decisions, communicate, manage the network, create mechanisms for knowledge generation and transfer, and oversee conflict mediation. Therefore, governance is designed to coordinate the strategies of the different actors and their different objectives and preferences (Kickert et al., 1997; Blanco et al., 2011). Thus, governance helps establish patterns of behaviour and, consequently, minimise uncertainty (Gulati, 1995).

According to Cristofoli et al. (2014), this set of instruments is associated with hierarchical organisations. However, Marques et al. (2011) argue that the interaction and 
interdependence among participants leads to the need for coordination, that is, the establishment of instruments and processes to influence the behaviour of those involved. There is also a need to use measures to monitor the achievement of goals and to establish either formal or informal control mechanisms. The latter refers to frequent interactions, meetings, negotiations, and the establishment of codes of conduct.

Provan \& Kenis (2005) in turn state that the bigger the network, the more difficult it is to outline tasks. Consequently, it is likely to adopt more centralised forms of governance. Provan \& Milward (1995) demonstrate that the effectiveness of networks is partly linked to the fact that they are coordinated by a central agency. The reason is that centralisation seems to facilitate integration and coordination, given that decentralised systems have difficulties in performing activities in a proposed time due to the large number of organisations and connections involved. For Provan \& Kenis (2008), governance can take on different forms, with the main form being self-governed structures. They feature decision-making based on periodic actors' meetings or frequent informal interactions: lead organisations, which concentrate on decisionmaking and activities coordination; and network administrative organisations where an independent organisation governs the network. However, even recognising the more horizontal forms of governance, the authors reaffirm that the more it is centralised, the more effective is the network.

McGuire (2006) also argues that the presence of lead organisations influences the effectiveness of governance by acting as controllers or facilitators. They can reduce the complexity of self-governance and increase the legitimacy of the network. However, even with centralised coordination, strategic activities still occur at the network level, with the lead organisation being responsible for administrative and operational activities.

However, Cristofoli et al. (2014) challenge the thesis of centralisation as a necessary factor for the achievement of performance. The authors show that networks with shared governance-formalised coordination mechanisms combined with administration activities-have a positive impact on performance. In this vein, Cristofoli \& Markovic (2016) argue that the centralisation of the structure and the abundance of resources affect performance, besides giving shape to coordination mechanisms, network management, and a combination of these factors. That is, effectiveness is possible even in cases of shared governance, provided that the relationships are structured through bureaucratic coordination processes that organise the participants' efforts towards a common goal. They conclude that at this juncture, bureaucracy fills the gaps of coherence, reliability, transparency, and uniformity by defining the relationships, rules, roles, and responsibilities.

\section{Methodology}

In line with Hill \& Lynn (2004), this study adopts a descriptive direction that enables us to understand the problems and strategies of governance processes through formal theories and model application. Thus, the analysis was based on the case of the ACDC network. We sought to understand its constitution, coordination structure, and functioning. We also sought to follow some of the propositions of Eisenhardt (1989), such as reviewing the literature, specifying the constructs and population of the case study, and using flexible instrumentation and multiple researchers as well as various literature resources. An important part of this work was the in-depth analysis of the case, with attention to specificities that could clarify assumptions and conclusions about the type of governance and help understand the management processes. Therefore, 
this research is a qualitative study with a descriptive character that uses the single case study method (Yin, 2003).

The selection of this case concerns its specificity. The ACDC network brings together different actors-non-governmental organisations (NGOs), state and municipal departments, schools, universities, public and private companies, and the State Ministry of Education. In addition, it arose from Law 10.639/2003 and was not established as a mandated network in which the legislative or administrative agent or contractor forces the participation of its members and assumes coordination. It was the result of a perceived opportunity opened by the institution of the law, which brought together the actors involved, who had convergent goals and awareness of the need to share resources. Therefore, unlike other networks involving the state, this was a private institution that assumed coordination. In contrast, public agents were subordinated to the coordination exercised by the Roberto Marinho Foundation. Public and private institutions participated, including NGOs linked to education and racial movements. Moreover, investments in ACDC reached BRL nine million. The funds, in turn, facilitated the training of a total of 110,102 educators (teachers, coordinators, etc.), comprising the direct training of 26,517 educators and 9,791 social educators; and the indirect training of 53,033 educators and 20,761 social educators.

In the operationalization of the method, we studied secondary data such as articles, theses, dissertations, official documents, and documents posted on the website, material developed by the network, meeting reports, e-mails exchanged, evaluation surveys, contracts, and other internal documents. Primary data were also collected through interviews with network designers, sponsorship negotiators, governance team leaders, pedagogical coordinators, and representatives of the implementing institutions. We conducted open interviews with three representatives of the project management team. We also used semi-structured questionnaires to interview 19 representatives of partner institutions. Table 1 lists the dates and duration of the interviews.

Table 1. Schedule of interviews conducted.

\begin{tabular}{cccccc}
\hline Interview & Institution & Interviewees & Place & Date & Duration \\
\hline 1 & FRM & 1,2 & Rio de Janeiro & 04.04 .12 & $01: 54$ \\
\hline 2 & FRM & $1,2,3$ & Rio de Janeiro & 06.20 .12 & $02: 17$ \\
\hline 3 & FRM & 1,2 & Rio de Janeiro & 08.09 .12 & $01: 17$ \\
\hline 4 & FRM & 1,2 & Rio de Janeiro & 09.20 .12 & $00: 43$ \\
\hline 5 & FRM & 5 & Rio de Janeiro & 08.28 .12 & $01: 20$ \\
\hline 6 & FRM & 1 & Rio de Janeiro* & 09.24 .12 & $01: 24$ \\
\hline 7 & NEAB/UFU & 7 & $\begin{array}{c}\text { Uberlândia - } \\
\text { Minas Gerais }\end{array}$ & 10.01 .12 & $02: 04$ \\
\hline 8 & UFMG & 8 & $\begin{array}{c}\text { Belo Horizonte - } \\
\text { Minas Gerais }\end{array}$ & 10.08 .12 & $00: 51$ \\
\hline 9 & IJC & 9 & $\begin{array}{c}\text { Fortaleza - } \\
\text { Ceará }\end{array}$ & 10.10 .12 & $01: 53$ \\
\hline 10 & UFPR & 10 & Curitiba - Paraná & 10.16 .12 & $01: 17$ \\
\hline 11 & N' ZINGA & 11 & $\begin{array}{c}\text { Belo Horizonte - } \\
\text { Minas Gerais }\end{array}$ & 10.16 .12 & $01: 18$ \\
\hline 12 & GELEDÉS & 12 & São Paulo & 10.17 .12 & $00: 55$ \\
\hline 13 & Ação Educativa & 13 & São Paulo & 10.22 .12 & $01: 40$ \\
\hline 14 & CEAP-NBLAC & 14 & Rio de Janeiro & 10.29 .12 & $00: 43$ \\
\hline
\end{tabular}


Table 1. Continued...

\begin{tabular}{cccccc}
\hline Interview & Institution & Interviewees & Place & Date & Duration \\
\hline 15 & INDEC & 15 & $\begin{array}{c}\text { Nova Iguaçu - } \\
\text { Rio de Janeiro }\end{array}$ & 11.01 .12 & $00: 55$ \\
\hline 16 & ACEAA/UCAM & 16 & Rio de Janeiro & 11.02 .12 & $01: 05$ \\
\hline 17 & $\begin{array}{c}\text { Cons. } \\
\text { Pedagógica }\end{array}$ & 4 & Rio de Janeiro & 11.02 .12 & $01: 09$ \\
\hline 18 & FRM & 18 & Rio de Janeiro* & 11.06 .12 & $00: 39$ \\
\hline 19 & FRM & 19 & Rio de Janeiro* & 11.06 .12 & $00: 31$ \\
\hline 20 & FRM & 20 & Rio de Janeiro & 11.07 .12 & $02: 10$ \\
\hline 21 & MEC & 21 & Espírito Santo & 11.15 .12 & $00: 45$ \\
\hline 22 & FRM & 22 & Rio de Janeiro* & 11.21 .12 & $02: 09$ \\
\hline 23 & FRM & 2 & Rio de Janeiro & 12.19 .12 & $04: 00$ \\
\hline
\end{tabular}

* Interviews held on site.

The selection of the interviewees was intentional and based on their ability to provide complete and accurate information. In addition, the data collected warrants special attention because of their relevance and confidentiality for the organisations (Flick, 2004). Interviews were conducted both on-site and by videoconference, between April and December 2012.

Considering that the present study seeks to understand how the ACDC network coordination instruments have behaved and how they have been perceived, as well as the functions/dysfunctions of its elements, the following analytical categories were considered: network coordination, status, and power dimensions (see Table 2).

Table 2. Analytical Categories.

\begin{tabular}{|c|c|}
\hline \multicolumn{2}{|c|}{ Coordination structure, power and status dimensions } \\
\hline \multirow{3}{*}{$\begin{array}{l}\text { Coordination } \\
\text { Instruments }\end{array}$} & Rules (Heranz, 2010; Magee \& Galinsky, 2008) \\
\hline & $\begin{array}{l}\text { Management and governance structure (Sørensen \& Torfing, 2007; } \\
\text { Provan \& Kenis, 2008; Gulati et al., 2012); Protocols, routines, } \\
\text { contracts, councils, and committees, decision-making and } \\
\text { communication processes, knowledge management and conflict } \\
\text { mediation (Cristofoli et al., 2014); Formal system of roles and } \\
\text { functions (Magee \& Galinsky, 2008) }\end{array}$ \\
\hline & $\begin{array}{l}\text { Mechanisms to monitor objectives achievement (Marques et al., } \\
\text { 2011) }\end{array}$ \\
\hline Power & $\begin{array}{l}\text { Asymmetric resource control (Magee \& Galinsky, 2008; Saz- } \\
\text { Carranza et al., 2015). }\end{array}$ \\
\hline Status & $\begin{array}{l}\text { Respect, esteem, and admiration directed at individuals or groups } \\
\text { (Magee \& Galinsky, 2008). }\end{array}$ \\
\hline
\end{tabular}

Table 3. Coordination structure, power and status dimensions and their impacts on the ACDC network

\begin{tabular}{|c|c|c|}
\hline Evidence & Functions & Dysfunction \\
\hline \multicolumn{3}{|l|}{ Coordination Instruments } \\
\hline \multicolumn{3}{|c|}{ Rules (Heranz, 2010; Magee \& Galinsky, 2008) } \\
\hline $\begin{array}{l}\text { "... Any new material needed the } \\
\text { approval from the coordination. } \\
\text { We were not allowed to put in }\end{array}$ & $\begin{array}{l}\text { - They offered } \\
\text { transparency, reliability, } \\
\text { and uniformity. }\end{array}$ & $\begin{array}{l}\text { - There were elements that } \\
\text { hierarchised the ACDC, by } \\
\text { establishing subordination }\end{array}$ \\
\hline
\end{tabular}


Table 3. Continued...

\begin{tabular}{|c|c|c|}
\hline Evidence & Functions & Dysfunction \\
\hline \multicolumn{2}{|l|}{$\begin{array}{l}\text { new material without the } \\
\text { approval of the National } \\
\text { Pedagogical Coordination } \\
\text { Commission..." (Interviewee 10) }\end{array}$} & $\begin{array}{l}\text { and classificatory order } \\
\text { among the network } \\
\text { components. }\end{array}$ \\
\hline \multicolumn{3}{|c|}{$\begin{array}{l}\text { Management and governance structure (Sørensen \& Torfing, 2007; Provan \& Kenis, } \\
\text { 2008; Gulati, Puranam \& Tushman, 2012); Protocols, routines, contracts, councils and } \\
\text { committees, decision-making and communication processes, knowledge management } \\
\text { and conflict mediation (Cristofoli et al., 2014); Formal system of roles and functions } \\
\text { (Magee \& Galinsky, 2008) }\end{array}$} \\
\hline \multirow{2}{*}{$\begin{array}{l}\text { "It was very controlled by the } \\
\text { ACDC team... there was little } \\
\text { spontaneous communication. } \\
\text { The network members } \\
\text { understood that a relationship } \\
\text { among them was not welcome. } \\
\text { So, there was some fear that } \\
\text { this was crossing a certain } \\
\text { boundary." (Interviewee 13). }\end{array}$} & $\begin{array}{l}\text { - The coordination } \\
\text { structure was the } \\
\text { repository of knowledge } \\
\text { and a central element of } \\
\text { communication and } \\
\text { exchange of experience. }\end{array}$ & $\begin{array}{l}\text { - There were few } \\
\text { opportunities for interaction } \\
\text { and exchange between } \\
\text { actors, and communication } \\
\text { was little explored. }\end{array}$ \\
\hline & - & $\begin{array}{l}\text { - A tendency towards } \\
\text { bureaucratisation and } \\
\text { centralisation of network } \\
\text { management. }\end{array}$ \\
\hline \multirow[t]{3}{*}{$\begin{array}{l}\text { "[...] Tensions have always } \\
\text { existed and have been adjusted } \\
\text { by the recognition that I am from } \\
\text { institution X and I applied to } \\
\text { work on a Canal Futura [...] It } \\
\text { was almost a boss-employee } \\
\text { relationship." (Interviewee 12). }\end{array}$} & $\begin{array}{l}\text { - The existence of } \\
\text { unilaterally negotiated } \\
\text { conflicts with } \\
\text { coordination, which } \\
\text { ensured agility in } \\
\text { decision-making. }\end{array}$ & $\begin{array}{l}\text { - A hierarchical decision- } \\
\text { making process. }\end{array}$ \\
\hline & - & $\begin{array}{l}\text { - There was little room for } \\
\text { negotiation. }\end{array}$ \\
\hline & $\bullet$ & $\begin{array}{l}\text { - The centralised } \\
\text { management model limited } \\
\text { networking. }\end{array}$ \\
\hline \multicolumn{3}{|c|}{ Mechanisms to monitor objectives achievement (Marques et al., 2011) } \\
\hline \multirow[t]{2}{*}{$\begin{array}{l}\text { The Petrobras monitoring } \\
\text { system has precisely all } \\
\text { information, from all stages of } \\
\text { the Project... (Interviewee 6). }\end{array}$} & $\begin{array}{l}\text { - It allowed to deliver and } \\
\text { systematise information } \\
\text { to Petrobras. }\end{array}$ & $\begin{array}{l}\text { - Coordinating instruments } \\
\text { gave order network } \\
\text { participants, generating } \\
\text { hierarchy. }\end{array}$ \\
\hline & $\begin{array}{l}\text { - It gathered a large } \\
\text { number of processes and } \\
\text { control mechanisms, } \\
\text { generating effectiveness. }\end{array}$ & $\bullet$ \\
\hline \multicolumn{3}{|l|}{ Power } \\
\hline \multicolumn{3}{|c|}{ Asymmetric resource control (Magee \& Galinsky, 2008; Saz-Carranza et al., 2015). } \\
\hline $\begin{array}{l}\text { The attributes that the channel } \\
\text { possess has to do with } \\
\text { management. I think it is, } \\
\text { precisely, their expertise with } \\
\text { product content management, } \\
\text { both written and audiovisual. } \\
\text { More than that, their ability on } \\
\text { community mobilisation, i.e. to } \\
\text { mobilise and articulate } \\
\text { networks. (Interviewee 22). }\end{array}$ & $\begin{array}{l}\text { - Different skills were } \\
\text { considered fundamental } \\
\text { to the existence and } \\
\text { functioning of networks. }\end{array}$ & $\begin{array}{l}\text { - It established power } \\
\text { between network } \\
\text { components. }\end{array}$ \\
\hline $\begin{array}{l}\text { Firstly, the institution established } \\
\text { a partnership with both the } \\
\text { Ministry of Education and }\end{array}$ & $\begin{array}{l}\text { - FRM invited the actors } \\
\text { and consequently } \\
\text { structured the network. }\end{array}$ & $\begin{array}{l}\text { - This action conferred } \\
\text { formal authority. }\end{array}$ \\
\hline
\end{tabular}


Table 3. Continued..

Evidence

SEPPIR. The other attribute was the production kits containing all the products [...]. It was an institution that had this media capability [...] They also acted as 'financial leadership' when establishing a relationship with Petrobras, the project's funding institution. (Interviewee 10).

The project team precisely followed every step taken by FRM. Everything from $A$ to $Z$ (Interviewee 2).

"But everything goes through the "A Cor" team, and so, many decisions were concentrated there. There was a way to get involved, as long as one did not mess with the project or did not affect the methodology of the work. There was interactivity, yes, a collective participation up to a point." (Interviewee 12)

Status

Respect, esteem, and admiration directed at individuals or groups (Magee \& Galinsky, 2008).
The area already has experience in other successful projects, as well as in articulation or even in content development. [...] Among all the FRM team, this one has the highest number of connections in the social world (Interviewee 19).

When you are going to talk to an educational secretariat about a theme "as easy as this one" [sic], offering a project, it helps a lot if you have brands such as FRM, TV Globo, Petrobras, the Federal Government [...] You always know that is a serious project, you know that it sound structured, that it is not something small, simple, or even unqualified. (Interviewee 6).

\section{- FRM controlled all - Exerted strong pressure to} actions developed, ensuring compliance with the schedule and established in the project.

- FRM was responsible for the quality of the developed products. meet what had been established in the initial planning. 
related to the study and to code the material according to the analytical categories, which were constructed based on propositions presented in the theoretical framework.

\subsection{The case of "The Colour of Culture" network}

The management committee was composed of the following institutions: Canal Futura; the Documentation and Information Center of the Black Artist (Centro de Documentação e Informação do Artista Negro - CIDAN); the Roberto Marinho Foundation (Fundação Roberto Marinho - FRM); the Ministry of Education/Secretariat for Continuing Education, Literacy, Diversity, and Inclusion (Ministério da Educação/Secretaria de Educação Continuada, Alfabetização, Diversidade e Inclusão - MEC/SECADI); Petrobras; the Secretariat of Policies to Promote Racial Equality (Secretaria de Políticas de Promoção da Igualdade Racial - SEPIR); TV Brasil; and TV Globo. Its purpose was to implement Law 10.639/2003 in Brazilian school networks, which mandated the teaching of Afro-Brazilian History and Culture in basic education.

Figure 1 shows the network structure. The management committee was responsible for the macro-strategy, which was defined during ordinary bi-monthly meetings. The FRM team comprised the Executive Management Group and was responsible for coordinating and managing administrative and financial resources. The editorial committee was responsible for the content and its adaptations. The group of implementers was responsible for transferring this content to the working group formed by the educators, who were responsible for implementing the project in the field.

MANAGEMENT COMMITTEE: Responsible for the network`s macro-strategy. Composed of members of the network of articulators (Canal Futura; CIDAN; FRM; MEC/SECADI; Petrobras ; SEPIR; TV Brasil e TV Globo).

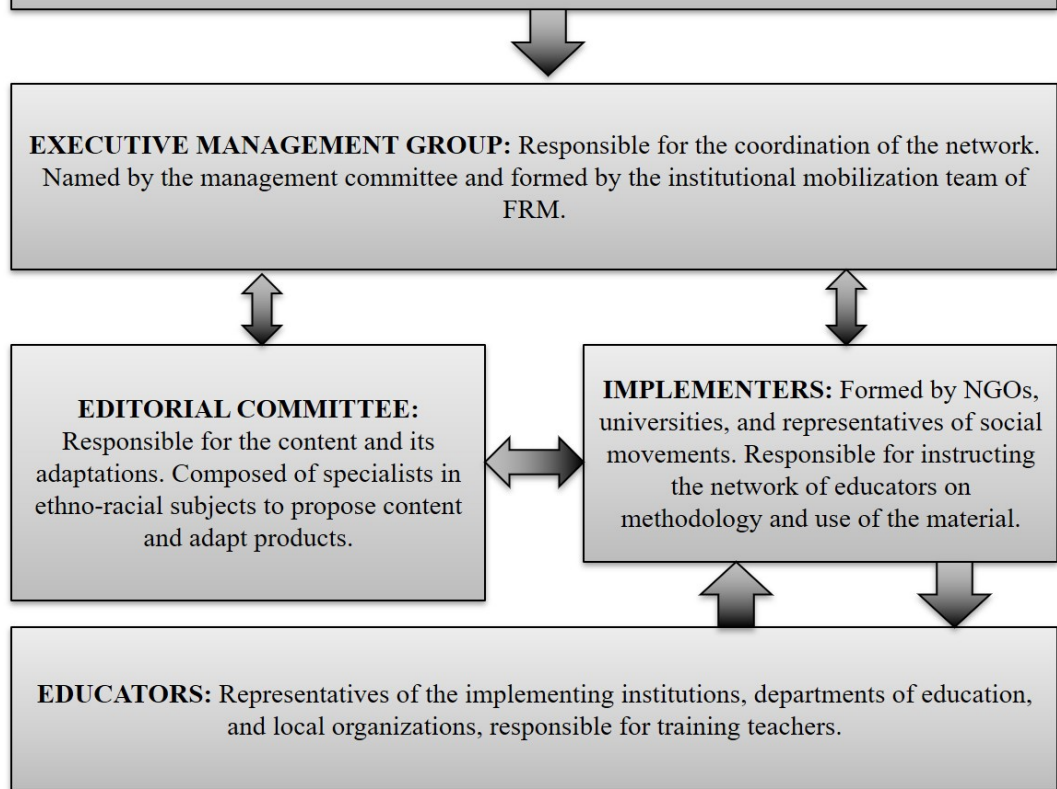

Figure 1. Interaction between committees and working groups of the ACDC governance network. Source: Prepared by the authors. 
Formal relations were established between four partners: Canal Futura as an organiser; Petrobras as a funder; and MEC and SEPIR as supporters. The umbrella contract placed FRM as the coordinator and established assignments, responsibilities, and sanctions. The other contracts, signed between FRM and member institutions, regulated the specific relationships. As noted above, FRM was responsible for general coordination, establishing the guidelines for the other components. The other institutions were responsible for implementation.

\subsection{Coordination and decision-making process}

The executive management group monitored all the daily actions of the project. The domain of the implementers incorporated shared management between the institutions, which had the autonomy to make necessary adjustments based on the needs of the educators. However, the executive management group had to be informed of these changes. Both the state and municipal departments and the executive management group were responsible for the relationship with the educators.

However, managing the different groups and meeting all the requirements of the contract demanded the centralisation of decision-making in the executive management group. It happened so because of the periodic indicators and evaluations provided to monitor performance. All members of the network collected data. First, local coordinators would compile data and send them to the national coordination group, which, in turn, prepared the final version of the report. The national coordinators established the pace of work, number of meetings, coordinator trips, arrangements with departments of education, dynamics of work with educators, etc.

\subsection{Information flow}

The different working groups had regular meetings, phone calls, or e-mails to foster communication in the network. There was also a virtual platform for them to post questions, reports, and analyses. This platform had a forum to discuss and gather information about what was happening in the field. Simultaneously, there was an informal communication network to exchange information, knowledge, and experiences. In general, there was a flow of communication at all network levels.

\subsection{Performance indicators}

The management committee presented performance reports, evaluations, and results for the activities performed during its regular meetings. Within the group of implementers, there were semi-annual meetings to evaluate progress. The group of educators generated reports about activities developed in the field to send their evaluations to the executive management team, who used these reports to observe, control, and share information. The executive management group centralised the monitoring process, based on the established indicators agreed upon with Petrobras. 


\section{Case analysis and discussion}

In the literature, some researchers argue that networks are horizontal arrangements (Rhodes, 1997; Phillips et al., 2000; Hardy et al., 2003; Sørensen \& Torfing, 2007; Sørensen, \& Torfing, 2005; Borzel \& Panke, 2007; Lopes \& Baldi, 2009; Wachhaus, 2011), whereas others view networks as arrangements that can be guided by a hierarchical orientation (Provan \& Kenis, 2005; Heranz, 2010; Agranoff, 2006; Provan \& Kenis, 2008; Emerson et al., 2012; Cristofoli et al., 2014; Grandori, 2001). The use of management tools (such as the division of roles and the definition of commitments, rules, formal and informal protocols, and mechanisms for conflict resolution, decisionmaking, control, and others) is what appoints the network orientation. Magee \& Galinsky (2008) argue that these elements characterise a hierarchy, that is, the definition of order, opening space for coordination and subordination, of an implicit or explicit classificatory ordering of individuals/groups. This hierarchy can be informal, based on status, power, and on the way that the network's members use or perceive some coordination instruments. It was through the observation of the ACDC network that we could understand how these elements worked together. Besides, the case allowed the observation of network members' perceptions towards those elements.

\subsection{Network coordination}

For Marques et al. (2011), the establishment of formal or informal managerial instruments/processes allow the coordination of the network. It induces the adoption of behaviours and ensures the achievement of the desired performance (Heranz, 2010). In addition, it is the number of participants in the network that determines the type of coordination required and the level of centralisation (Provan \& Kenis, 2005). In turn, this centralisation in lead organisations reduces the complexity of self-governance (McGuire, 2006). In ACDC, as predicted by Heranz (2010), Agranoff (2006), Nielsen (2010), Marques et al. (2011), Whelan (2011), Emerson et al. (2012), Cristofoli et al. (2014), and Cristofoli \& Markovic (2016), different contracts and processes governed the relationships among partners, whose purpose was to set up guidelines that governed their actions.

\section{"... Any new material needed the approval from the coordination group. We were not allowed to put in new material without the approval of the National Pedagogical Coordination Commission..." (Interviewee 10).}

The control exercised by the coordination group was due to requirements outlined in the contract signed with the project funder, Petrobras. The reports showed the expected schedule, and goals and results that were achieved (Marques et al., 2011). These coordination instruments gave order to the network participants and allowed the coordination to deliver information to Petrobras. All these procedures involved many processes and control mechanisms, which aimed to record what was happening on the field.

The Petrobras monitoring system has all the information from all stages of the project in a precise manner. So, if I have to train 3,000 educators, I have to name the 3,000 people. The same happens with all the educational secretariats I have to work with. If I have to do any task, I have to insert this information in system. I have to tell who did it ... everything!. (Interviewee 6). 
In line with Cristofoli \& Markovic (2016), the centralisation and formalisation of coordination mechanisms offered transparency, reliability, and uniformity in defining relationships, rules, roles, and responsibilities and were essential to the ACDC operations. On the other hand, the network participants perceived the centralisation and formalisation of coordination mechanisms as elements that hierarchised the $A C D C$, as they established subordination, ordering positions among the network components, as predicted by Magee \& Galinsky (2008).

Schreiner et al. (2009) emphasise the importance of social bonding in collaborative environments. However, according to the interviewees, ACDC favoured vertical connections. That is, there were mechanisms to communicate and to exchange experiences and knowledge between the FRM and each of the working groups. However, it did not promote such exchanges among all members of the network. For this reason, most respondents stated there were few opportunities for interaction and information exchange between their counterparts. Consequently, the communication between them was little explored. The coordination group amalgamated all the feedback and was a central element in the communication process and the exchanges of experience. This circumstance created a space for conflicts to emerge.

It was very controlled by the ACDC team... there was little spontaneous communication. The network members understood that a relationship among them was not welcome. So, there was some fear that this was crossing a certain boundary. (Interviewee 13).

The decision-making process was also viewed as hierarchical because, although there were discussions among the working groups, the final decision belonged to the central coordination structure. There were cases in which there was no room for negotiation, therefore, these conflicts were negotiated unilaterally.

Tensions have always existed and have been adjusted by the recognition that I am from institution $X$ and I applied to work on a Canal Futura project. Therefore, I recognise this channel, this group as the management group responsible for this project. It was almost a boss-employee relationship. (Interviewee 12).

The initial reaction of several network participants was frustration, given that the network was expected to be more horizontally structured. Consequently, there was an expectation that the governance structure would be more flexible, with greater opportunities for interaction and exchanges. In this sense, in contrast to what Sørensen \& Torfing (2007) predicted, the centralised management model limited network performance. Those authors state that in collaborative environments, coordination structures distinguish from traditional ones, favouring negotiation processes and rules supporting the self-regulation theory. The analysis of the coordination instruments used by the ACDC network has revealed the opposite.

Finally, the main reason for the creation of ACDC was to implement Law $10.639 / 2003$ in the Brazilian network of schools. The creation of a network to cover a country as large as Brazil demanded bureaucratic coordination/control process, like the one identified by Heranz (2010). Its structure showed a high degree of formalisation of written contracts, information collection/standardisation, communication process, and regular services. Besides, the coordination aimed to comply with legal requirements and provide public services in general. These features showed a tendency towards network bureaucracy, given its characteristics. In this sense, the similarity between 
network bureaucratic coordination tools and hierarchical organisation is of no mere coincidence. Thus, this leads to questions about how power relations and status could moderate or intensify coordination mechanisms regarding the perception of hierarchy.

\title{
4.2 Status/Power
}

As discussed by Magee \& Galinsky (2008), status and power are the two elements that form a hierarchy. They can be observed through the recognition of an organisation's competence in a given subject/topic (status) and the possibility for an actor to set agendas, norms for discussion, rules for behaviour, and standards for thought based on the resources that it possesses (power).

In the case of ACDC, FRM shows different competencies that were fundamental for the existence and operation of the network. In this respect, its trajectory in creating attractive programs and educational materials is highlighted. Their experience stands out in communication, mobilisation, and training of educators in different parts of the country; in operating networks focused on education; in the experience acquired by their mobilisation team; in positive goals reached with several projects; the development and articulation of quality content; and the capacity to mobilise institutions.

\begin{abstract}
The attributes that the channel possesses are related to the management. I think it is precisely their expertise with product content management, both written and audiovisual, and in addition, with their ability on community mobilisation i.e. to mobilise and articulate networks. (Interviewee 22).
\end{abstract}

The area already has experience in other successful projects, as well as in articulation or even in content development. Of course, the content area of Canal Futura also supports the mobilisation, and this experienced team leads the project. Among all the FRM team, this one has the highest number of connections in the social world. (Interviewee 19).

Therefore, in terms of status, it is important to consider FRM's prior experience in creating networks. It guarantees a positive status concerning mastery in the formulation, conduct, and effectiveness of instruments, processes, and contracts. Additionally,, essential technical resources, such as audiovisual and communication resources, and necessary relationships and reputation for setting up the network, are instrumental.

\footnotetext{
When you are going to talk to an educational secretariat about a theme "as easy as this one" [sic], offering a project, it helps a lot if you have brands such as FRM, TV Globo, Petrobras, the Federal Government. [...] You know that it is a serious project, you know that it sounds structured, that it is not something small, simple, or even unqualified. (Interviewee 6).
}

It was the coordination that invited the actors to participate in the network. According to Gulati et al. (2012), one of the mechanisms for constituting a relationship that replaces formal authority is choosing members, establishing criteria, and identifying partners. 
Firstly, the institution established a partnership with both, the Ministry of Education and SEPPIR. The other attribute was the production of kits containing all the products, and that was a very interesting thing. It was an institution that had this media capability, which for us is very important, and it was important to develop the project. They also acted as 'financial leadership' when establishing a relationship with Petrobras, the project's funding institution. (Interviewee 10).

In ACDC, FRM exerted great control over the partnership, which came from its previous relationship with Petrobrás. To meet the demands of the latter, FRM controlled all developed actions and exerted strong pressure to meet the schedules agreed upon in the initial planning. The project team precisely followed every step taken by FRM. Everything from A to Z. (Interviewee 2).

Additionally, FRM took responsibility for the products developed by the different working groups to maintain the characteristics specified in the project.

But everything goes through the "A Cor" team, and so, many decisions were concentrated there. There was a way to get involved, as long as one did not mess with the project or did not affect the work methodology. There was interactivity, yes, and collective participation up to a point. (Interviewee 12).

FRM also applied tables with objectives, indicators of both processes and results, control mechanisms, and records to report what occurred in the field. The need for information delivery, contract fulfilment, and the implementation of the law justify the use of these instruments, as stated by the coordination.

The contract established the coordination of ACDC and its functions, i.e., the definition of roles and paths. The different working groups, which formed the network, should follow these roles and paths. In most cases, the networks' components perceived the instruments as relevant, regarding both their roles of providing guidelines for partners' actions and conciliating conflicts. On the other hand, these factors point to, in the perspective of the networks' members, the exercise of inherent elements of power.

Through the network's rules, procedures, and coordination mechanisms and joint action with Petrobras, the executive management group exercised power in ACDC. The reports to control and measure the delivery of results, to a certain extent, granted the working groups to keep pace. The data requested impacted the number of meetings, coordination trips, arrangements with education departments, and the implementation time of the different activities. Therefore, it is conclusive that the financial and technical resources set the agendas, discussions, and dynamics of the network. As proposed by Magee \& Galinsky (2008), ACDC coordination established agendas, discussion topics, rules, and so on, based on their status bestowed upon by the remaining acting parties and the available resources.

\section{Concluding remarks}

This article was devoted to understanding the relationship between the coordination structure of the ACDC network and its hierarchy. Specifically, it sought to understand whether ACDC can be characterised as a self-regulated network or as a hierarchical arrangement and to identify the functions/dysfunctions of the network's coordination elements. 
According to the above, the interaction between actors in a network leads to the adoption of coordination mechanisms, which are fundamental for the establishment of a minimum order to achieve the desired results. Thus, contracts, routines, processes, mechanisms of communication and control, and the measurement of results must be established. However, it is observed that the establishment of these elements can generate a certain dysfunction, which can be the perception of hierarchical relations. If this is a true statement, and it seems to be, given that it is accepted by several researchers, then it can therefore, be argued that networks, for most part, are not fully horizontal.

In the case of the ACDC network, these hypotheses have been confirmed. However, because we analysed a single case, we have a methodological limitation that does not allow us to infer that this situation applies to other networks. However, the results presented here open the door for future assessments that include the following questions: Is it the adoption of these mechanisms that establish the hierarchy? Or is it how they are adopted? Is it the manner in which they are adopted that characterises their use as elements of power and status? Are the establishment of intense communication and decision-making processes important counterpoints? That is, are these key for power and status to not be established as elements of hierarchy?

In general, this case study has brought several contributions that can be presented as a theoretical advance in the literature on collaborative governance, particularly regarding the hierarchy of these arrangements. In addition, this study also contributes by raising propositions involving managerial issues and issues related to the actors who participated in ACDC.

\subsection{From the conceptual theoretical perspective}

Concerning the established coordination model, we must note the perspective raised from the case for the development of specific governance knowledge about partnerships between governments, companies, and civil institutions, which, as noted in the literature, remains an open question. In this sense, the case highlighted the importance of leadership performed by FRM in the network (Emerson et al., 2012; Nielsen, 2010).

In particular, the case contributes to the debate about self-regulation or more horizontal structures and their implications for the desired results and the perceptions of the actors involved. In elucidating the concept of social hierarchy, it points to a method of analysing the coordination structures and instruments used in networks from a different perspective. In general, the authors do not discuss the consequences of establishing these mechanisms concerning the perception of those involved.

The ACDC network had a coordinating and decision-making structure, viewed by many respondents as centralised. It can be argued that the communication process was efficient, given that it provided a constant exchange between the managing committee, FRM, and the different working groups (of implementers and educators) and their components. However, it was not sufficient in providing a better approximation of the different understandings of the division of roles throughout the network and the adjustments of expectations of different actors. This opens up perspectives for the evaluation of the relationship between the establishment of coordination mechanisms, centralisation, communication, and the hierarchisation of the network.

Another aspect noted by the study, although preliminary because it is a single case study, concerns the possibility of a connection between the perception of less 
involvement of the partners, given the hierarchical structure, and the lower circulation, generation, and exchange of knowledge. This is an important question that has yet to be investigated and answered.

\subsection{From the managerial perspective}

An interesting aspect regarding network management is the expectations of the participants. There is a common understanding that networks are horizontal structures, in which hierarchy is not present. If the hypothesis supported by the ACDC case is a reality in different networks, then their managers must learn to manage these expectations. In the context of ACDC, many of the issues raised during the interviews indicated this misalignment, to the frustration of some members of the network, which led to conflicts.

We also add that the case is a relevant experience not only for the achievement of its results but also mainly for the development of an original management model that can serve as a basis for other partnership managers. Furthermore, by emphasizing the importance of understanding the intricacies of the coordination structure and the specificities of the actors involved, it is a source of learning for other experiences.

\section{References}

Agranoff, R. (2006). Inside collaborative networks: ten lessons for public managers. Public Administration Review, 66(s1), 56-65. http://dx.doi.org/10.1111/j.1540-6210.2006.00666.x.

Agranoff, R., \& McGuire, M. (2001). Big questions in public network management research. Journal of Public Administration: Research and Theory, 11(3), 295-326. http://dx.doi.org/10.1093/oxfordjournals.jpart.a003504.

Bardin L. (2009). Análise de conteúdo. Lisbon: Edições 70.

Blanco, I., Lowndes, V., \& Pratchett, L. (2011). Policy networks and governance networks: towards greater conceptual clarity. Political Studies Review, 9(3), 297-308. http://dx.doi.org/10.1111/j.1478-9302.2011.00239.x.

Borzel, T., \& Panke, D. (2007). Network governance: effective or legitimate? In: E. Sorensen, J. Torfing (Ed.). Theories of democratic network governance. New York: Palgrave Macmillan. http://dx.doi.org/10.1057/9780230625006_9.

Cristofoli, D., \& Markovic, J. (2016). How to make public networks really work: A qualitative comparative analysis. Public Administration, 94(1), 89-110. http://dx.doi.org/10.1111/padm.12192.

Cristofoli, D., Markovic, J., \& Meneguzzo, M. (2014). Governance, "management" and performance in public networks: how to be successful in shared governance networks. The Journal of Management and Governance, 18(1), 77-93. http://dx.doi.org/10.1007/s10997012-9237-2.

Denhardt, J. V., \& Denhardt, R. B. (2015). The new public service revisited. Public Administration Review, 75(5), 664-672. http://dx.doi.org/10.1111/puar.12347.

Eisenhardt, K. M. (1989). Building theories from case study research. Academy of Management Review, 14(4), 532-550. http://dx.doi.org/10.5465/amr.1989.4308385.

Emerson, K., Nabatchi, T., \& Balogh, S. (2012). An Integrative Framework for Collaborative Governance. Journal of Public Administration: Research and Theory, 22(1), 1-29. http://dx.doi.org/10.1093/jopart/mur011.

Flick, U. (2004). Uma introdução à pesquisa qualitative. Porto Alegre: Bookman. 
Grandori, A. (2001). Neither hierarchy nor identity: knowledge-governance mechanisms and the theory of the firm. The Journal of Management and Governance, 5(3-4), 381-399. http://dx.doi.org/10.1023/A:1014055213456.

Gulati, R. (1995). Does familiarity breed trust? the implications of repeated ties for contractual choice in alliances. Academy of Management Journal, 38(1), 85-112. http://dx.doi.org/10.2307/256729.

Gulati, R., Puranam, P., \& Tushman, M. (2012). Meta-organization design: rethinking design in interorganizational and community contexts. Strategic Management Journal, 33(6), 571586. http://dx.doi.org/10.1002/smj.1975.

Hardy, C., Phillips, N., \& Lawrence, T. B. (2003). Resources, Knowledge and Influence: The Organizational Effects of Interorganizational Collaboration. Journal of Management Studies, 40(2), 321-347. http://dx.doi.org/10.1111/1467-6486.00342.

Heranz, J. (2010). Network Performance and Coordination. Public Performance \& Management Review, 33(3), 311-341. http://dx.doi.org/10.2753/PMR1530-9576330301.

Hill, C. J.., \& Lynn, L. E. (2004). Is hierarchical governance in decline? Evidence from empirical research. Journal of Public Administration: Research and Theory, 15(2), 173-195. http://dx.doi.org/10.1093/jopart/mui011.

Kickert, W. J. M., Klijn, E., \& Koppenjan, J. F. M. (1997). Managing complex networks: strategies for the public sector. London: Sage Publications.

Klijn, E.-H., \& Skelcher, C. (2007). Democracy and governance networks: compatible or not? Public Administration, 85(3), 587-608. http://dx.doi.org/10.1111/j.1467-9299.2007.00662.x.

Koppenjan, J. (2008). Creating a playing field for assessing the effectiveness of network collaboration by performance measures. Public Management Review, 10(6), 699-714. http://dx.doi.org/10.1080/14719030802423061.

Krippendorff, K. (2004). Content analysis. An introduction to its methodology (2nd ed.). Thousand Oaks, CA: Sage Publications.

Lopes, F. D., \& Baldi, M. (2009). Redes como perspectiva de análise e como estrutura de governança: uma análise das diferentes contribuições. Revista de Administração Pública, 43(5), 1007-1035. http://dx.doi.org/10.1590/S0034-76122009000500003.

Magee, J. C., \& Galinsky, A. D. (2008). Social hierarchy: the self-reinforcing nature of power and status. The Academy of Management Annals, 2(1), 351-398. http://dx.doi.org/10.5465/19416520802211628.

Malhotra, D., \& Lumineau, F. (2011). Trust and collaboration in the aftermath of conflict: the effects of contract structure. Academy of Management Journal, 54(5), 981-998. http://dx.doi.org/10.5465/amj.2009.0683.

Marques, L., Ribeiro, J., \& Scapens, R. (2011). The use of management control mechanisms by public organizations with a network coordination role: a case study in the port industry. Management Accounting Research, 22(4), 269-291. http://dx.doi.org/10.1016/j.mar.2011.09.001.

McGuire, M. (2006). collaborative public management: assessing what we know and how we know It. Public Administration Review, 66(s1), 33-43. http://dx.doi.org/10.1111/j.15406210.2006.00664.x.

Nielsen, B. B. (2010). Strategic fit, contractual, and procedural governance in alliances. Journal of Business Research, 63(7), 682-689.

Phillips, N., Lawrence, T. B., \& Hardy, C. (2000). Inter-organizational collaboration and the dynamics of institutional fields. Journal of Management Studies, 37(1), 22-43. http://dx.doi.org/10.1111/1467-6486.00171.

Provan, K. G., \& Kenis, P. (2005). Modes of network governance and implications for public network management. In Proceedings of the Eighth National Public Management Research Conference. Los Angeles, CA: University of Southern California. 
Provan, K. G., \& Kenis, P. (2008). Modes of network governance: structure, management, and effectiveness. Journal of Public Administration: Research and Theory, 18(2), 229-252. http://dx.doi.org/10.1093/jopart/mum015.

Provan, K. G., \& Milward, H. B. (1995). A preliminary theory of interorganizational network effectiveness: a comparative study of four community mental health systems. Administrative Science Quarterly, 40(1), 1. http://dx.doi.org/10.2307/2393698.

Rhodes, R. (1997). Understanding governance. Buckingham: Open University Press.

Saz-Carranza, A., Salvador Iborra, S., \& Albareda, A. (2015). The power dynamics of mandated network administrative organizations. Public Administration Review, 76(3), 449-462. http://dx.doi.org/10.1111/puar.12445.

Schreiner, M., Kale, P., \& Corsten, D. (2009). What really is alliance management capability and how does it impact alliance outcomes and success? Strategic Management Journal, 30(13), 1395-1419. http://dx.doi.org/10.1002/smj.790.

Sørensen, E., \& Torfing, J. (2005). The democratic anchorage of governance networks. Scandinavian Political Studies, 28(3), 195-218. http://dx.doi.org/10.1111/j.14679477.2005.00129.x.

Sørensen, E., \& Torfing, J. (2007). Theories of democratic network governance. Basingstoke: Palgrave MacMillan. http://dx.doi.org/10.1057/9780230625006.

Wachhaus, T. A. (2011). Anarchy as a model for network governance. Public Administration Review, 72(1), 33-42. http://dx.doi.org/10.1111/j.1540-6210.2011.02481.x.

Whelan, C. (2011). Network dynamics and network effectiveness: a methodological framework for public sector networks in the field of national security. Australian Journal of Public Administration, 70(3), 275-286. http://dx.doi.org/10.1111/j.1467-8500.2011.00735.x.

Williamson, O. E. (1991). Comparative economic organization: the analysis of discrete structural alternatives. Administrative Science Quarterly, 36(2), 269. http://dx.doi.org/10.2307/2393356.

Yin, R. K. (2003). Case study research: design and methods (3rd ed.). London: Sage. 